\title{
The Role of Short-Chain Fatty Acids in the Interplay between a Very Low-Calorie Ketogenic Diet and the Infant Gut Microbiota and Its Therapeutic Implications for Reducing Asthma
}

\author{
Naser A. Alsharairi $\mathbb{C}$ \\ Heart, Mind \& Body Research Group, Menzies Health Institute Queensland, Griffith University, \\ Gold Coast 4222, Australia; naser.alsharairi@gmail.com
}

Received: 15 November 2020; Accepted: 14 December 2020; Published: 16 December 2020

\begin{abstract}
Gut microbiota is well known as playing a critical role in inflammation and asthma development. The very low-calorie ketogenic diet (VLCKD) is suggested to affect gut microbiota; however, the effects of VLCKD during pregnancy and lactation on the infant gut microbiota are unclear. The VLCKD appears to be more effective than caloric/energy restriction diets for the treatment of several diseases, such as obesity and diabetes. However, whether adherence to VLCKD affects the infant gut microbiota and the protective effects thereof on asthma remains uncertain. The exact mechanisms underlying this process, and in particular the potential role of short chain fatty acids (SCFAs), are still to be unravelled. Thus, the aim of this review is to identify the potential role of SCFAs that underlie the effects of VLCKD during pregnancy and lactation on the infant gut microbiota, and explore whether it incurs significant implications for reducing asthma.
\end{abstract}

Keywords: ketogenic diet; asthma; SCFAs; infant gut microbiota; pregnancy; lactation

\section{Introduction}

Low carbohydrate diets (LCDs) can be highly heterogeneous in terms of carbohydrate (CHO) content and quality, with no consensus on its precise definition [1], and for this reason it is difficult to interpret comparisons of results between studies. The very low-calorie ketogenic diet (VLCKD), a popular type of $\mathrm{LCD}$, is similar to the modified Atkins regime in terms of restricting $\mathrm{CHO}$ while emphasizing a high-fat regimen [2]. As the VLCKD seems to be an area of growing interest in preventing and treatment of several diseases [3-8], evidence of its effect on the gut microbiota is inadequate and still ongoing in animal models and humans [9]. In fact, thevery low-calorie diet (VLCD) contributes to gut microbiota remodelling in humans [10], and "keto microbiota," which refers to a gut microbiota shaped by a ketogenic diet (KD), and may play a major role in enhancing the response of the host to therapy [11]. The low $\mathrm{CHO}$, adequate protein and high-fat $\mathrm{KD}$ has been found to be associated with increased beneficial gut microbiota-related profiles including Bacteroidetes phylum in children with refractory epilepsy. However, this increase occurs with respect to reducing the overall microbial diversity, probably due to the low $\mathrm{CHO}$ content of the diet, which can disrupt the abundance of other beneficial microbiota responsible for degrading complex $\mathrm{CHO}$ [11].

The symbiotic relationship that has evolved between humans and their gut microbiota provides several benefits for humans, including regulating host immunity, producing vitamins $\mathrm{K}$ and $\mathrm{B}$, protecting against pathogens, strengthening gut integrity and producing metabolites such as short chain fatty acids (SCFAs) [12]. The composition of the infant gut microbiota is driven by several factors, such as mode of delivery and feeding, maternal antibiotic use and nutrition and body mass index 
(BMI) [13]. The stability of the gut microbiota, reached between 2 to 18 years of age, is varied by phylum, with Bacteroidetes exhibiting the highest temporal stability [12].

The maternal gut microbiota is an extremely dynamic entity influenced by several perinatal factors, including diet, which may in turn influence the infant gut microbiota composition [13]. For this reason, establishing the influence of specific restricted dietary patterns such as VLCKD on the infant gut microbiota composition is of substantial additional importance. This pattern may positively or negatively influence the gut microbiota composition and its related effects on host health [9]. Different types of the KD exist (including standard, cyclical, targeted and high protein KD), but standard KD (VLCKD) is considered a highly restricted CHO diet [14]. The VLCKD is an extremely low CHO, high fat and moderate protein diet [15], which restricts $\mathrm{CHO}$ to less than $50 \mathrm{~g}$ per day [14-16], with a ratio of macronutrients being $70 \%$ from fat, $20 \%$ from protein and $10 \%$ from $\mathrm{CHO}$ [14]. The source of $\mathrm{CHO}$ (dietary fiber), fats (high in polyunsaturated fatty acid (PUFA), moderate in monounsaturated fatty acid (MUFA) and low in saturated fatty acid (SAT)) and plant-based protein should be highly considered when planning a VLCKD regimen, which plays a key role in shaping the function/composition of gut microbiota and producing SCFAs [17-19]. The VLCKD can lead to a metabolic state called "ketosis", which results in increased liver ketone bodies (KBs) production [20], and may in some cases (type 1 diabetes, gestational diabetes) lead to a pathological state called diabetic ketoacidosis (DKA), where too many KBs accumulate in the blood, causing it to become highly acidic [21].

Oxidative stress is an important feature of airway inflammation in asthmatic children [22]. It is hypothesized that $\beta$-hydroxybutyrate $(\beta \mathrm{OHB})$, a major component of $\mathrm{KBs}$, is significant in reducing oxidative stress by inhibiting reactive oxygen species (ROS)/superoxide production and improving mitochondrial activity $[23,24]$. It has also shown anti-inflammatory effects by inhibiting the leucine-rich-containing family, pyrin domain-containing-3 (NLRP3) inflammasome-mediated inflammatory chronic disease $[20,23]$. Therefore, it is particularly important to determine whether adherence to a VLCKD during pregnancy and lactation has a beneficial effect on childhood asthma. Indeed, the clinical relevance of such effects is yet to be investigated. Changes in the gut microbiota are associated with various pathological states, and it has been suggested that imbalance of the gut microbiota (dysbiosis) increases the risk of developing asthma later in life [25]. Gut dysbiosis is characterized by increased levels of Proteobacteria and decreased levels of Veillonella, Lachnospira, Rothia, Roseburia and Faecalibacteria in asthmatic children [26,27]. The VLCKD can significantly change the gut microbiota composition of pediatric patients [9], suggesting that gut microbiota should be taken into consideration as a potential alternative therapeutic treatment for asthma. The VLCKD therapeutic effect may result from metabolic reprogramming and epigenetic markers as mechanisms with gut metabolites $[28,29]$, where all may be involved in altering the infant gut mictobiota, thereby reducing the risk of asthma. The exact mechanisms underlying the effect of VLCKD in pregnancy and lactation against childhood asthma are still largely unknown. Therefore, this review aims to provide an overview of whether the VLCKD use influences the infant gut microbiota composition and the protective effects thereof on asthma. Herein, the paper highlights the role of gut metabolites SCFAs as potential mechanisms that may underlie these effects.

\section{Methods}

A non-systematic search of the published literature is conducted between 1 January 2000, and 30 November 2020, in the PubMed database using the following keywords: KD, KBs, asthma, pregnancy, lactation/breastfeeding, SCFAs, epigenetic, gut inflammation, pro-inflammatory cytokines and the infant gut microbiota. Searches include reviews/systematic reviews, meta-analysis, randomized controlled trials (RCTs)/experimental studies and observational studies (case-reports, cross-sectional, case-control, cohort) published in English. 


\section{Ketone Body Metabolism}

The main metabolic pathways for ketone body metabolism include ketogenesis and ketolysis. Adherence to KD causes the body to enter the ketogenesis pathway to produce three main KBs: $\beta O H B$, acetoacetate (ACA) and acetone (least abundant) [20]. Ketogenesis takes place in the mitochondrial matrix of hepatocytes, where free fatty acids (FFAs) are released from adipose tissue during lipolysis under low insulin conditions, along with stimulating catecholamines, cortisol, glucagon and growth hormone secretion. FFAs are broken down via $\beta$-oxidation to acetyl-coenzyme A (acetyl-CoA), which is used as a precursor for the production of $\beta \mathrm{OHB}$ and ACA $[20,30]$. These are released into the circulation for use in extrahepatic tissues via the monocarboxylate transporter 1 (MCTI1), where the ketolysis process takes place. Once taken up by target tissues, $\beta \mathrm{OHB}$ is transformed to $\mathrm{ACA}$ via $\beta \mathrm{OHB}$ dehydrogenase $(\beta \mathrm{DH})$ and $\mathrm{ACA}$ is transformed back to acetyl-CoA via $\beta$-ketoacyl-CoA transferase $(\beta C T)$. Acetyl-CoA then goes through a thetricarboxylic acid (TCA) cycle to generate nicotinamide adenine dinucleotide (NADH) and flavin adenine dinucleotide (FADH2) via the oxidative phosphorylation pathway to produce adenosine triphosphate (ATP) [20,31]. The ketogenesis and ketolysis pathways are also active during starvation/fasting [20,24,32,33], and the periods of pregnancy and childbirth [24,34], where CHO availability is significantly diminished, or fatty acid levels are increased.

\section{Ketone Bodies as Epigenetic Modifiers in Asthma}

Epigenetic changes constitute the key regulator of gene expression and cellular metabolism, and their dysregulation may contribute to several diseases [35], including childhood asthma [36], where changes may start in utero following prenatal environmental exposures (e.g., maternal smoking, allergen, dietary supplements) or during early life [37]. Epigenetic changes in breastfed infants, particularly changes in DNA methylation patterns, may be influenced by breastfeeding, but further studies are needed to explore the role of epigenetic mechanisms in the associations between breastfeeding and asthma [38]. DNA methylation, non-coding RNA and histone modifications are the most common epigenetic mechanisms existing in childhood asthma, which can regulate gene expression through effects on chromatin structure and contribution to gene silencing [39,40].

Epigenetic changes are influenced by KBs [11], and the $\beta \mathrm{OHB}$ not only regulates cellular processes such as signaling metabolites [41], but also influences the gut microbiota and increases butyrogenesis [42], in which epigenetic mechanisms are involved [43,44]. Ketosis has been linked to epigenomic reprogramming and displays as covalent KB-induced histone post-translational modifications, including histone methylation (Kme), histone/lysine acetylation $(\mathrm{Kac})$ and $\beta$-hydroxybutyrylation $(\mathrm{Kbhb})$, which regulate chromatin architecture and gene expression during adherence to KD, DKA and fasting ketosis [45]. Kac and Kbhb consider the key epigenetic mechanisms for activation of $\beta \mathrm{OHB}$ to modulate immune cell function and inflammation [46]. The $\beta \mathrm{OHB}$, an endogenous histone deacetylase (HDACs) inhibitor, has a well-known protective role against oxidative stress. In animal models, adherence to $\mathrm{KD}$, which increases $\beta \mathrm{OHB}$ levels, is associated with increased histone Kac at the promoter regions of the forkhead box (Foxo3a) and metallothionein 2A (Mt2), which targets oxidative stress resistance genes activated by HDAC class I and II inhibitors [45-47]. In response to high levels of $\beta \mathrm{OHB}$, histone Kbhb levels with site-specific lysine residues (H3K4, H4K8, H3K9, H4K12, H3K56) are elevated significantly in human embryonic kidney 293 (HEK293) cells during prolonged fasting, suggesting that lysine Kbhb at these residues regulates chromatin structure and functions [43]. HEK293 cells are found to transiently transfect with ORM (yeast)-Like protein isoform 3 (ORMDL3) mRNA expression, an asthma susceptibility gene located on chromosome 17q21 in children [48]. ORMDL3 suppresses the sarco-endoplasmic reticulum $\mathrm{Ca}^{2+}$ pump (SERCA) leading to a decreased endoplasmic reticulum (ER) $\mathrm{Ca}^{2+}$ concentration and activating unfolded-protein response (UPR) signaling pathway [49]. This pathway can induce increased expression of chemokines, metalloproteases and activating transcription factor (ATF6) in lung epithelial cells, which are involved in the pathogenesis of asthma [50]. $\beta \mathrm{OHB}$ suppresses inflammation via 
inhibition of protein expression of ER stress response pathway (known as UPR). It also enhances both Foxp3 and manganese superoxide dismutase (MnSOD) transcription through AMP-activated protein kinase (AMPK) activation, a cellular energy sensor which regulates energy homeostasis, leading to a reduction in the level of cellular oxidative stress [51]. This suggests that $\beta \mathrm{OHB}$ may regulate histone $\mathrm{Kbhb}$ and protect HEK293 cells against oxidative stress via suppressing ER stress. Taken together, $\beta \mathrm{OHB}$ acts as a potent epigenetic modifier and exerts its anti-inflammatory effect providing potential targeted therapy in asthma through mechanisms for epigenetic regulation.

\section{Short-Chain Fatty Acids: A Link between Maternal VLCKD, the Infant Gut Microbiota and the Potential Role in Reducing Asthma}

The link between VLCKD during pregnancy and lactation, the infant gut microbiota and the potential role in reducing asthma is still unknown. Exposure to antenatal and postnatal factors (e.g., maternal nutrition, antibiotic exposure, maternal microbiota, skin contacts, maternal smoking and mode of delivery and feeding), which are known triggers of asthma, also have the potential to alter DNA and histone methylation of several genes [28,52,53], resulting in altered lung function in the offspring [52]. Gut microbial metabolites have been considered as substrates/cofactors for mediating the relationship between host epigenetic markers and alterations in gut microbiota composition [54]. The gut microbiota produced SCFAs as epigenetic cofactors/substrates, which induce changes of DNA methylation and histone modifications [28,29], and thereby, have potential value as underlying mechanisms. Maternal nutrition during pregnancy and lactation plays a significant role in modulating the infant gut and milk microbiota composition [13]. However, how maternal diet, particularly VLCKD, epigenetically determines asthma phenotypes in the next generation of offspring is still undetermined. Importantly, it would be interesting to understand how the VLCKD during pregnancy and lactation, as a result of the influence of SCFAs, can modulate the infant gut microbiota profile, which could in turn lead to specific epigenetic changes, resulting in a modified risk of asthma in offspring.

Several studies showed that maternal diet during pregnancy, particularly the macronutrient composition of VLCKD (SFA, omega-3 PUFA, linoleic ( $\omega-6)$ fatty acid, vegetable protein) and the dietary patterns characterized by high intake of these nutrients, may promote SCFAs production through diverse microbiota in the maternal and infant gut [13,55-61]. Breast milk feeding of many different microbial species may explain the increased abundance of these species in the infant gut and vice versa, suggesting vertical transmission during breastfeeding via the entero-mammary pathway. This pathway involves the passage of diverse microbes from the lumen of the mother's gut by dendritic cells (DCs)/macrophages during late pregnancy, and subsequently, translocates them to the lactating mammary glands through the lymphatic system and/or blood stream $[62,63]$. The gut microbiota is able to produce SCFAs in breast milk, which can pass through the maternal gut into the mammary gland via the systemic circulation [64], suggesting SCFAs may transfer to the infant gut through the breast milk. Dietary macronutrient intake in the VLCKD during lactation may produce SCFAs and influence the infant gut SCFA-producing bacteria by influencing the breast milk microbiota [13].

\subsection{Short-Chain Fatty Acids}

The SCFAs, acetate, propionate and butyrate (in a molar ratio at 3:1:1), constitute the dominating microbial fermentative end-products of undigested/unabsorbed dietary $\mathrm{CHO}$ (mainly fiber and resistant starch), and to a relatively minor extent, endogenous proteins (peptides and amino acids) in the colon $[65,66]$. Acetate is the most dominant circulating metabolite in the feces of breastfed infants, followed by propionate and butyrate $[67,68]$. Lactate is a major intermediate metabolite present in high levels in the feces of infants $[67,68]$, where it acts with acetate as substrates for butyrate production by certain enteric bacterial species [67]. Fecal acetate is accumulated in high levels in the colon of adults, whereas lactate is detected at low levels, as they may act as a substrate for butyrate and propionate-producing bacteria $[66,67]$. Diets high in resistant starch are linked to an increase in the fecal butyrate levels in healthy adults [69]. SCFAs driven by maternal gut microbiota are also likely 
detected in breast milk. A few studies have revealed that butyrate and acetate are the most abundant SCFAs in breast milk [64,70,71]. Butyrate and acetate levels in breast milk are found to be significantly lower in atopic than non-atopic women [64].

SCFAs are mainly produced by the Firmicutes phylum. Butyrate is produced by acetate and/or lactate-utilizing butyrate-producing bacteria through the butyryl-CoA: acetate CoA-transferase pathway $[65,72,73]$. This pathway is typically present in Lachnospiraceae (including Eubacterium hallii, Eubacterium rectale, Roseburia intestinalis, Coprococcuscatus) and Ruminococaceae (including Faecalibacterium prausnitzii) within the phylum Firmicutes, in which acetyl-CoA and butyrate are formed from butyryl-CoA and the transformation of the CoA moiety to the external acetate molecule $[66,72,73]$. The Clostridium spp. belonging to the Firmicutes phyla are also able to produce butyrate through the butyrate kinase pathway $[66,74]$. Other probiotic bacteria, such as Bifidobacterium and lactobacillus spp., utilize lactate and produce SCFAs, which exert anti-inflammatory effects in immune cells through an epigenetic mechanism such as butyrate-associated HDAC inhibition [53].

SCFAs have emerged as significant mechanisms linking diet, gut microbiota and the pathogenesis of asthma [65], and thereby, have become a significant therapeutic target for inhibiting lung pro-inflammatory responses [75]. SCFAs play a significant role in regulating host immune homeostasis, which are essential for accumulation and/or differentiation of the colonic regulatory $T$ cells $\left(T_{\text {regs }}\right)[76,77]$. Defects in $\mathrm{T}_{\text {regs }}$ function contribute to the failure of its ability to suppress an excessive Th2 response, which may promote the development of allergic asthma [78]. Butyrate acts as an HDAC inhibitor via the activation of G-protein coupled receptors (GPCRs) and FFA receptors (FFA2, FFA3) to enhance $\mathrm{T}_{\text {regs }}$ differentiation and DCs [79-82]. Butyrate is able to ameliorate gut inflammation by blocking nuclear factor- $\mathrm{KB}(\mathrm{NF}-\mathrm{\kappa B})$ activation in intestinal B-lymphocytes and induce regualtion of peroxisome proliferator-activated receptor gamma(PPAR $\gamma$ ) expression [53].The NF- $\mathrm{kB}$ transcription factor binds to the inhibitor of kappa B (IкB) proteins, which is phosphorylated by kappa B kinase (IKK), in particular IKK- $\beta / \mathrm{IKK}-2$, via the canonical pathway, leading to the enhancement of its transactivation potential in lung epithelial cells, where it affects inflammatory genes, leading to asthma $[83,84]$. Butyrate is considered an anti-allergic asthma treatment, which suppresses pro-inflammatory cytokines secretion and GATA binding protein 3 (GATA3) expression in the human pulmonary Group 2 Innate lymphoid cells (ILC2s) [82]. ILC2s play a role in the production of pro-inflammatory cytokines, and overexpression of the transcription factor GATA3 increased the expression of stimulation-expressed gene 2 (ST2) and thymic stromal lymphopoietin (TSLP) receptors in the human pulmonary ILC2, leading to the development of asthma $[85,86]$.

SCFAs produce a strong synergistic effect with VLCKD in inducing ketosis [87]. The combination of $\beta$ OHB-butyrate in relation to ketogenic initiatives is sensible [87]. The VLCKD is characterized by reducing the proportion of dietary $\mathrm{CHO}$ to a certain level $[3,14,15]$, which may result in lowering the amount of dietary fiber intake [88]. This decrease in dietary fiber has the greatest potential to cause dysbiosis of the infant gut microbiota, which is associated with reduced butyrate-producing species, including $R$. intestinalis and F. prausnitzii. This ultimately leads to a weakened immune response and potentially contributes to asthma [89]. There is some evidence suggesting maternal dietary fiber intake or high acetate levels during pregnancy may reduce the risk of asthma in offspring. In one experimental study, a high-fiber diet during late pregnancy is shown to promote gut species belonging to the Bacteroidetes phylum, which produces high levels of acetate. Acetate suppresses estalished allergic airways disease in offspring by inhibiting HDACs (mainly HDAC9), leading to Foxp3 transcription, which enhances $T_{\text {regs }}$ number and function. Foxp3 binds upstream of the fetal lungnitrate reductase catalytic subunit (NAPA) gene located on chromosome 1p36 to inhibit atrial natriuretic peptide (ANP) production [90], a molecule associated with asthma [91]. Another experimental study found that, compared with butyrate and propionate, high fecal SCFA acetic acid levels are associated with dietary fiber intake during pregnancy and reduced asthma risk with allergic sensitization [92]. 


\subsection{SCFA-Producing Bacteria: A Potential Regulatory Role in Reducing Asthma}

A review of the evidence shows that tumor necrosis factor (TNF- $\alpha$ ), interferons (IFN- $\alpha /$ INF- $\beta$ ) and interleukins (IL-1 $\alpha /$ IL-1 $\beta$, IL-4-IL-6, IL-10, IL-13, IL-15-IL-20, IL-25, IL-31-IL-33) play a key role in the pathogenesis of allergic asthma [93]. This section presents SCFA-producing bacteria, and their potential therapeutic implications for reducing asthma.

\subsubsection{Bifidobacterium spp.}

Bifidobacteria, referred to as Human-Residential Bifidobacteria (HRB), are Gram-positive anaerobic non-motile bacteria with highguanine-plus-cytosine (GC) content, which belong to the species Bifidobacterium within the Actinobacteria phylum [94,95]. Diets enriched in plant protein, unsaturated fat/low fat, high fiber/resistant starch and polyphenols increase gut abundance of Bifidobacteria [96]. Infants with a low relative abundance of Bifidobacterium are at higher risk of developing asthma later in life [97]. Evidence from human RCTs/experimental studies showed that the presence of Bifidobacterium spp. and strains resulted in regulated immune responses and improved the production of anti-inflammatory cytokines in infants, suggesting that Bifidobacterium could be of great potential as a therapeutic approach for reducing asthma. B. longum subsp. infantis has been shown to display anti-inflammatory properties through the production of indole-3-lactic acid (ILA), a breastmilk tryptophan metabolite, which acts through the aryl hydrocarbon receptor (AHR) mRNA expression and suppressed lipopolysaccharide (LPS)-induced IL-8 in premature intestinal enterocytes [98,99]. It also exerts its anti-inflammatory activity using a toll like receptor (TLR-4) as a mediator to inhibit IL-1 $\beta$-induced IL-6 secretion and downregulates IL-1 receptor-associated kinase 2 (IRAK-2) mRNA expression in H4 cells [100], a common adapter protein associated with susceptibility to early-onset asthma [101]. Supplementation with B. subspecies infantis strain EVC001 is considered safe and tolerable by exclusively breastfed infants [102], and results in decreased production of IL-1 $\beta$ over the 60 days postnatal [103]. B. infantis strain R0033 supplementation exerts anti-inflammatory effects as indicated by an increase in the IL-10/IL-12 ratio, while the increase of the TNF- $\alpha / \mathrm{IL}-10$ ratio demonstrates a pro-inflammatory effect in infants following ingestion of Lactobacillus helveticus (L. helveticus) strain R0052 [104].

B. longum subsp. infantis, B. bifidum, B. longum subsp. longum and B. breve strains produce higher levels of ILA than adult-type and non-HRB strains [105], and an aromaticlactate dehydrogenase (LDH) gene from these strains is responsible for the production [106], suggesting ILA production by these strains may contribute to the inhibition of pro-inflammatory cytokines in asthma. The B. bifidum strain B536 isolated from infant feces has been found to display an inhibitory effect on LPS-induced IL-10 secretion [107]. The B. bifidum strains NCC189, S16, S17 [108] and Bif3 [109] exert inhibitory effects on LPS-stimulated NF- $\kappa B$ activation and mRNA/protein expression of IL- 8 and TNF- $\alpha$ incolon adenocarcinoma cell line (HT-29) cells. The B. longum strain Lon4 inhibits LPS-TNF- $\alpha$-dependent IL-8 mRNA/protein expression levels in HT-29 cells [109]. Probiotic supplementation with B. longum strain BB536 in healthy full-term infants enhances Th1/Th2 immune response through reducing the ratio of IFN- $\gamma / \mathrm{IL}-4$ and the number of IFN- $\gamma$ secretion cells [110]. Treatment of HT-29 cells with B. breve strain Bre10 suppresses LPS and TNF- $\alpha$-induced IL- 8 mRNA and protein expression levels [109]. The B. breve strain M-16V colonizing the breastfed infant gut is regarded as safety [111], and exerts anti-inflammatory effects on allergic diseases after a single supplementation [111,112], or in combination with B. infantis M-63 and B longum BB536 [113], including both prenatal and postnatal periods [114].The probiotic B. breve strain M-16V and galacto/fructo-oligosaccharide (GOS/FOS) prebiotic mixture supplemented with fortified milk increase the relative abundances of Bifidobacterium spp. [115]. Probiotic supplementation with $B$. breve in preterm infants increases the production of serum transforming growth factor (TGF- $\beta$ ) levels, and enhances the deca-pentaplegic homolog 3 (Smad3) mRNA expression for TGF-A signaling molecules [116]. Treatment with microRNA (miR-744) mimic results in a significant decrease in the proliferation rate of bronchial epithelial cells in severely asthmatic children, and an increase of TGF- $\beta 1$ mRNA abundance in these cells via regulating the 
Smad3 signaling pathway [117], suggesting that $B$. breve may enhance regulatory TGF- $\beta 1$ and produce anti-inflammatory effects in asthma. Taken together, these findings suggest that various probiotic strains of the species Bifidobacterium longum subsp. infantis, bifidum, longum subsp. longum and breve have the potential to alleviate gut inflammatory responses in infants, which may reduce the risk of developing allergic asthma.

\subsubsection{Lactobacillus spp.}

Lactobacillus are key members of the gram-positive facultative anaerobe rod-shaped lactic acid bacteria (LAB) with low GC content $[94,118]$, which belong to class Bacilli within phylum Firmicutes [94,119], and are considered to be $\mathrm{D}(-), \mathrm{L}(+)$ and DL-Lactic acid producers [120]. The Mediterranean diet (MED), characterized by consumption of plant protein, unsaturated fat/low fat, fiber/resistant starch and polyphenols has been found to increase the gut abundance of lactobacillus [96]. Early infancy colonization with Lactobacillus spp. reduces the risk of allergic asthma later in life [121]. Reduced abundances of Lactobacillus spp. are found in infants born to pregnant women with asthma [122]. Lactobacillus spp. and strains may be considered as potential therapeutic strategies against asthma in early infancy. Lactobacillus spp. isolated from breast milk showed anti-adhesion activity against enteric pathogens on intestinal epithelial cells and immunomodulation properties by suppressing IL-8 expression [123]. Specific isolated Lactobacillus strains from the infant feces display potential anti-inflammatory properties in vitro. L. fermentum BioE LF11 and L. plantarum BioE LPL59 showed anti-inflammatory properties through inhibiting LPS-stimulated IL-6 secretion [124]. L. gasseri 4M13 and L. rhamnosus 4B15 exhibit the highest cholesterol-lowering and anti-inflammatory activities by reducing cholesterol uptake from the intestine, and suppressing IL-6, IL-1 $\beta$, IL-10 and mRNA expression of cytokine genes in the LPS-stimulated HT-29 cells [125]. L. rhamnosus JL-1 exerts a strong anti-inflammatory ability to attenuate infant gut inflammation induced by LPS stimulation through downregulation of the mRNA and protein expression of inflammatory genes (IL-6, IL-1 $\beta$ and TNF- $\alpha$ ) in Caco-2 cells [126]. L. paracasei CNCM I-4034 demonstrates high anti-inflammatory activity as indicated by reduced pro-inflammatory cytokines (IL-6, chemokines and TNF- $\alpha$ ) secretion in DCs [127]. One prospective study showed that early gut colonization with Staphylococcus aureus (S. aureus) in the presence of $L$. rhamnosus GG is associated with decreased production of IL-4 and IL-10 at two years of age compared to $S$. aureus alone, suggesting that L. rhamnosus $G G$ exerts anti-inflammatory effects by suppressing S. aureus-induced pro-inflammatory cytokine production, and may modulate the immune responses and the risk of asthma [128]. These findings suggest that Lactobacillus strains as potential probiotics may contribute to reducing asthma by their ability to exert its immunomodulatory effect in the infant gut against LPS-induced inflammation.

\subsubsection{Bacteroides spp.}

Bacteroides are Gram-negative anaerobic rod-shaped motile bacteria $[94,96,129]$, which belong to the phylum Bacteroidetes [119]. The relative abundance of Bacteroides has been noted to increase with the intake of MED and animal fat/protein [96]. Bacteroides strains belonging to the species B. fragilis, B. thetaiotaomicron and B. vulgatus exert anti-inflammatory effects and immune regulation, which may contribute to their beneficial action in reducing asthma. B. fragilis exerts its immunomodulatory effects on cytokine production [130], and modulates the immunogenicity of LPS, which triggers pro-inflammatory cytokine production involved in gut inflammation [131]. B. fragilis has the ability to produce surface capsular polysaccharide A (PSA) by host DCs, which activates the TLR2 signaling pathway required to induce $\mathrm{CD}^{+} \mathrm{Foxp}^{+} \mathrm{T}_{\text {regs }}$ in vivo [131,132], and CD39+ Foxp3 ${ }^{+} \mathrm{T}_{\text {regs }}$ in vitro with marked suppression of LPS-induced monocyte TNF $\alpha$ [133]. Studies specifically investigating the effect of $B$. fragilis on immune development and asthma are limited. In a prospective study, colonization with $B$. fragilis at age 3 weeks is found to be associated with asthma at the age of 3 years. However, the study has the limitation that no tested fecal samples are obtained from mothers, so a complete recovery of $B$. fragilis strains in infants is unknown [134]. Another prospective study showed that early 
gut colonization with $B$. fragilis in high amounts at age 1 week and 1 month after birth is associated with suppressing TLR4 mRNA expression and LPS-induced IL-6 andC-C motif chemokine ligand (CCL4) at age 12 months [135], suggesting such bacterium may influence immune development and reduce the risk of asthma in later life.

B. thetaiotaomicron in vitro has the ability to produce regulatory IL-10 and protective IL-6 mediated by nanosized outer membrane vesicles (OMVs) [136]. B. thetaiotaomicron elicits anti-inflammatory activity in vitro through inducing nuclear export of the NF-kBrelaxedaspartate-auxotrophic (RelA)-PPAR $\gamma$ complex incolon carcinoma cell line (Caco-2) cells, causing downregulation of NF- $\mathrm{kB}$-driven pro-inflammatory genes such as TNF $\alpha$ [137]. The NF- $\mathrm{kB}$ pathways regulate T-cell differentiation via regulation the expression of pro-inflammatory genes in asthma, particularly those encoding IL-6 and TNF- $\alpha$ [138], suggesting that B. thetaiotaomicron may have a potential role in this regulation. $B$. vulgate has been acknowledged for their anti-inflammatory effect in vitro. The isolated $L_{B} S_{B v}$ and Lipid $A_{B v}$ from $B$. vulgatus have proven anti-inflammatory activity as evidenced by their stimulating low levels of TNF- $\alpha$, IL-6, C-X-C motif chemokine ligand (CXCL-8) production and NF-KB activation compared to that of Escherichia coli (E. coli) LPS [139]. This suggests that B. vulgatus may have a potential immunemodulatory role in the context of asthma by reducing LPS-induced inflammation. Further RCTs are needed to highlight the anti-inflammatory and immune-modulatory effect of B. thetaiotaomicron and B. vulgatus in neonatal intestinal epithelial cells via regulation of asthmatic cytokine gene expression.

\subsubsection{Enterococcus spp.}

Enterococcus, a gram positivefacultative anaerobe bacterium of the class Bacilli within the Firmicutes phylum [94,96,119], and with low GC content $[94,140]$, is among the earliest LAB colonizers of the intestine in the first few days after birth $[67,141]$. Diets enriched in wheat bran and whole grains act as a prebiotic that may result in significantly increased fecal abundance of enterococci [142]. Delayed colonization with Enterococcus in early life is associated with subsequent development of allergy [143], indicating that early gut Enterococcus colonization could significantly influence immune development and reduce the risk of asthma. Specific Enterococcus strains may exhibit anti-inflammatory and regulatory effects in reducing asthma. A recent experimental study has found that the E. faecalis strain BioE EF71 isolated from infant feces resulted in suppressing LPS-induced IL-6 secretion [124]. The E. faecalis strains (EC1, EC3, EC15 and EC16), which are isolated from infant feces, have been found to suppress tumor receptor associated factor (TRAF6), TLR3, TLR4 and TLR9 in Caco-2 and HT-29 cells [144], through suppressing the activation of p38 mitogen-activated protein kinase (P38 MAPK) and the c-JUN NH2-terminal kinase (JNK) signaling pathways [145]. Inhibition of these signals would enhance TGF- $\beta 1$ activation-induced connective tissue growth factor (CTGF) mRNA expression in asthmatic airway smooth muscle (ASM) cells and lung fibroblasts [146]. RCTs have shown evidence that p38 MAPK inhibition resulted in anti-inflammatory effects when used in combination with dexamethasone (synthetic glucocorticoid) on glucocorticoid receptor (GR) target gene expression through a significant reduction of LPS-induced IL-6 secretion associated with asthma in lung cells $[147,148]$. This suggests that E. faecalis may be involved in regulating inflammatory responses in infant lung cells and producing anti-inflammatory effects in asthma through immune-signaling pathways.

\subsubsection{Streptococcus spp.}

Streptococcus, mainly represented by S. salivarius and S. thermophilus GC-poor species [149], are the most predominant Gram-positive facultative anaerobe LAB of the class Bacilli within the phylum Firmicutes detected in both breast milk and the infant gut [150-154]. Consumption of high levels of unsaturated and low-fat diets appears to increase gut abundance of Streptococcus [96]. An imbalance in the gut microbiota between Streptococcus and other bacterial taxa appear to contribute to the development of allergic diseases in infants [155]. Specific probiotic Streptococcus strains have been 
shown to exert anti-inflammatory properties, which may help to reduce the risk of asthma in infants. A recent RCT has shown that infant formulas that included a combination of bioactive compounds (fermented formula) produced by $S$. thermophilus O65/B. breve C50 and prebiotic oligosaccharides increased fecal secretory immunoglobulin A (SIgA) levels in breastfed infants [156]. S. thermophilus strain BioE ST107 isolated from infant feces exhibits immunomodulatory effects through an attenuation of the LPS-stimulated increase in IL-6 levels [124]. In an experiment study, the S. thermophilus strain St065 isolated from breast-fed infant feces produces active bacterial metabolites (mainly pepsin/trypsin), which inhibited LPS-induced NF- $\mathrm{kB}$ activation and IL-10 secretion [107]. This suggests that probiotic strains of $S$. thermophilus attenuate an LPS-induced pro-inflammatory response and may be an adjuvant treatment of asthma.

\subsubsection{Blautia and Ruminococcus spp.}

Blautia spp., and in particular, B. wexlerae, B. luti, B. producta, B. hansenii and B. faecis, which belong to the family Lachnospiraceae within the phylum Firmicutes [94], constitute one of the most predominant Clostridium coccoides group (clade XIVa Clostridium) in infant feces [157-159]. Gut colonisation with Blautia spp. is influenced by early life dietary patterns. A recent prospective study found that unspecified Blautia spp. are positively associated with processed meat/savoury snacks/milk and inversely associated with meat/fish and eggs/beans over the first year of life [115], suggesting that Blautia may have the capacity to grow in foods rich in simple $\mathrm{CHO}$ and SAT.Most members of misclassified Ruminococci, including R. obeum, R. luti, R. bromii, R. productus and R. gnavus, which belong to the family Lachnospiraceae and clade IV Clostridium, are reclassified within the genus Blautia [160,161].

Studies on the gut colonization with Blautia/Ruminococcus and asthma risk in early infancy are limited. A recent prospective study revealed that individuals with a persistent gut colonization of Blautia and Ruminococcus are at high risk of asthma over the first year of life, though few infants display a significantly depleted in Blautia. It also shows that delayed gut microbial diversification observed in infants at high risk for asthma is remedied by daily supplementation with L. rhamnosus GG for 6 months [162]. An in vitro study revealed that the depletion of B. wexlerae and B. luti in obese children not only contributed to intestinal inflammation, but also to the development of insulin resistance and subsequent risk of diabetes. The study showed that gut colonization with these species is significantly less abundant in obese children (aged 5-14 years) than in lean counterparts. The study also showed that B. luti DSM 14534 and B. wexlerae F15 strains in lean children exert anti-inflammatory effects through reducing the ratio of IFN- $\gamma / \mathrm{IL}-4$ and TNF- $\alpha / \mathrm{IL}-4$ in peripheral blood mononuclear cells compared to the effects of B. vulgatus strain BAC-CCC-2. This suggests that such species may help to reduce inflammation and improve glucose metabolism in lean children [163]. A prospective twin cohort study showed that high fecal abundance of $R$. gnavus drives Th2 allergic asthmatic responses through increased secretion of colonic IL-25 and IL-33. However, it is not clear whether R. gnavus induces Th2 allergic responses through mechanisms of allergy development or its genes. The study suggests that R. gnavus should be considered as a therapeutic target for the treatment of asthma [164]. Another prospective study revealed that a low relative abundance of Ruminococcus in infant feces at 1 month of age is associated with TLR2-induced IL-6/TNF- $\alpha$ and subsequent eczema at 6 months [165]. Given that

Blautia and Ruminococcus spp. have been identified as butyrate-producing bacteria, further studies investigating its anti-inflammatory effects on immune-linked asthma in early infancy are needed.

\subsubsection{Faecalibacterium Prausnitzii}

F. prausnitzii is a Gram positive, anaerobe, rod-shaped and non-motile bacterium [96], which belongs to the family Ruminococcaceae and clade IV Clostridium within the phylum Firmicutes [131,166]. Consumption of animal protein and SAT increase the relative gut abundance of F. prausnitzii [96]. F. prausnitzii exerts an anti-inflammatory effect through inhibiting NF-kB activation and IL-10 production in asthmatic children [167]. F. prausnitzii in vitro stimulates intestinal function, as evident by the attenuated expression of NF-KB, IL-1 $\beta$ and TNF- $\alpha$ in Caco-2 cells [168]. 
An experimental study showed that $F$. prausnitzii induces human colonic DCs to prime $\mathrm{CD}^{+}$and CD39 ${ }^{+}$expression secreting IL-10 and IL-27, which are known as molecules that play a key role in Foxp $3^{+}-\mathrm{T}_{\text {reg }}$ generation and regulate asthma. F. prausnitzii in vitro suppresses LPS-induced expression of TNF- $\alpha /$ IL-12 and the JNK/MAPK signaling pathway activated by TLR2/6 ligands [169]. This suggests that $F$. prausnitzii inhibits LPS-mediated inflammation and induces colonic $\mathrm{T}_{\text {reg }}$ differentiation, which may help to reduce allergic asthma. Given the fact that children with increased risk of asthma had a low abundance of $F$. prausnitzii in early infancy $[25,97,162]$, further studies are needed to investigate the role of gut $F$. prausnitzii in infancy, and elucidate the mechanisms underlying the F. prausnitzii asthma interaction, and understand the means by which such bacteria could reduce the risk of allergic asthma in early childhood.

Table 1 shows studies addressing the anti-inflammatory effect of SCFA-producing bacteria in reducing the production of inflammatory mediators involved in the pathogensis of asthma.

Table 1. Summary of In Vitro Studies Demonstrating the Therapeutic Implications of SCFA-Producing Bacteria for Reducing Asthma in Infants.

\begin{tabular}{|c|c|c|c|}
\hline Microorganism/s & Type & Anti-Inflammatory Effects in Asthma & References \\
\hline B. infantis & Probiotic & $\downarrow$ LPS-induced IL-8, $\downarrow$ IL-1 $\beta$-induced IL-6 & [98-100] \\
\hline B. infantis EVC001, R0033 & Probiotic & $\begin{array}{c}\downarrow \mathrm{IL}-1 \beta, \uparrow \text { anti-inflammatory ratio } \\
\text { (IL-10/IL-12) }\end{array}$ & {$[103,104]$} \\
\hline $\begin{array}{l}\text { B. bifidum NCC189, S16, S17, Bif3, } \\
\text { B536, S. thermophilus St065 }\end{array}$ & Probiotic & $\downarrow$ LPS-induced IL-10 \&NF- $\kappa \mathrm{B}, \downarrow$ TNF- $\alpha$ & [107-109] \\
\hline B. longum Lon4, BB536 & Probiotic & $\downarrow$ LPS-induced TNF- $\alpha, \downarrow$ IFN- $\gamma /$ IL- 4 & {$[109,110]$} \\
\hline B. breve Bre10 & Probiotic & $\downarrow$ LPS \&TNF- $\alpha$-induced IL- 8 & [109] \\
\hline $\begin{array}{l}\text { L. fermentum BioE LF11, L. } \\
\text { plantarum BioE LPL59, E. faecalis } \\
\text { BioE EF71, S. thermophilus } \\
\text { BioE ST107 }\end{array}$ & Probiotic & $\downarrow$ LPS-induced IL-6 & [124] \\
\hline $\begin{array}{l}\text { L. gasseri } 4 \mathrm{M} 13, \text { L. rhamnosus } 4 \mathrm{~B} 15 \text {, } \\
\text { L. rhamnosus JL-1 }\end{array}$ & Probiotic & $\downarrow$ LPS-induced IL-6, IL-1 $\beta$, IL-10, TNF- $\alpha$ & {$[125,126]$} \\
\hline L. paracasei CNCM I-4034 & Probiotic & $\downarrow$ IL-6, TNF- $\alpha$ & [127] \\
\hline L. rhamnosus GG & Probiotic & $\downarrow \mathrm{IL}-4, \downarrow \mathrm{IL}-10$ & [128] \\
\hline B. fragilis & Commensal & $\downarrow$ IL-6, CCL4 & [135] \\
\hline E. faecalis EC1, EC3, EC15, EC16 & Probiotic & $\begin{array}{l}\downarrow \text { TNF receptor-associated factor } 6 \\
\text { (TRAF6), TLR3, TLR4, TLR9 }\end{array}$ & [144] \\
\hline S. thermophilus O65/B. breve C50 & Probiotic & $\uparrow \mathrm{SIgA}$ & [156] \\
\hline B. luti DSM 14534, B. wexlerae F15 & Probiotic & $\downarrow$ IFN- $\gamma / \mathrm{IL}-4, \downarrow$ TNF- $\alpha / \mathrm{IL}-4$ & [163] \\
\hline F. prausnitzii & Commensal & $\downarrow$ IL-10, NF-кB & [167] \\
\hline
\end{tabular}

$(\downarrow)$ decrease, $(\uparrow)$ increase; table derived from reference [170].

\section{Concluding Remarks}

The effects of VLCKD during pregnancy and lactation on the infant gut microbiota, and the mechanisms of its potential action in the treatment of asthma are still not fully understood. The VLCKD induces changes to the gut microbiota composition of pediatric patients, suggesting that the gut microbiota may hold a significant therapeutic potential to reduce asthma. The infant gut microbiota may be influenced by maternal VLCKD during pregnancy. The VLCKD during lactation may also directly influence the infant gut microbiota by influencing the breast milk microbiota. The VLCKD may lead to dramatic changes in epigenetic markers such as histone modification and DNA methylation. Epigenetic changes are also influenced by the KBs particularly $\beta O H B$, which exerts anti-inflammatory effects in vivo and in vitro. Adherence to VLCKD, a regimen low in CHO, high in fat and with moderate protein intake, leads to nutritional ketosis, which results in increased KBs production. 
The SCFAs as epigenetic metabolites produced by gut microbiota belongining to the Firmicutes phylum may play a key stabilizing role for underpinning VLCKD-infant gut microbiota interactions, which may in turn reduce asthma risk. Butyrate can regulate host immune homeostasis to exert anti-inflammatory effects by inhibiting the production of asthma-related inflammatory cytokines. Other intermediate metabolites such as lactate produced by intestinal Bifidobacterium and LAB is crucial in VLCKD-infant gut microbiota interactions, where it acts with acetate as substrates for butyrate production.

SCFA-producing bacteria play an immune-modulating role in reducing asthma. Maternal bacterial species produce SCFAs as key metabolites exerting anti-inflammatory properties through passing the infant intestinal barrier. Several studies support the use of specific probiotic strains in preterm infants, which can influence SCFAs production and downregulate asthma-related inflammatory cytokines and chemokines.

In conclusion, SCFAs are key microbial metabolites that mediate the relationship between VLCKD during pregnancy and lactation, and the infant gut microbiota. The VLCKD regimen, including sources of dietary fiber, fats (high in PUFA, moderate in MUFA and low in SAT) and plant-based protein, may influence SCFA-producing bacteria in gut microbiota, and therefore, lead to an anti-inflammatory state and a decreased risk of asthma. High-quality clinical trials are needed before VLCKD can be recommended for pregnant and lactating women. Further large prospective cohort studies to monitor the changes in maternal gut microbiota composition during pregnancy and lactation following VLCKD are needed. This highlights the importance of monitoring the side effects and evaluating the effects of VLCKD on the infant gut microbiota composition or diversity with the aim of reducing asthma, which is associated with gut dysbiosis.

Funding: This research received no external funding.

Conflicts of Interest: The author declares no conflict of interest.

$\begin{array}{ll}\text { Abbreviations } & \\ \text { ACA } & \text { Acetoacetate } \\ \text { Acetyl-CoA } & \text { Acetyl-coenzyme A } \\ \text { AHR } & \text { Aryl hydrocarbon receptor } \\ \text { AMPK } & \text { AMP-activated protein kinase } \\ \text { ANP } & \text { Atrial natriuretic peptide } \\ \beta C T & \beta \text {-ketoacyl-CoA transferase } \\ \beta \text { DH } & \beta \text { OHB dehydrogenase } \\ \text { BMI } & \text { Body mass index } \\ \beta O H B & \beta \text {-hydroxybutyrate } \\ \text { Caco-2 } & \text { Colon carcinoma cell line } \\ \text { CCL } & \text { C-C motif chemokine ligand } \\ \text { CHO } & \text { Carbohydrate } \\ \text { CTGF } & \text { Connective tissue growth factor } \\ \text { CXCL } & \text { C-X-C motif chemokine ligand } \\ \text { DCs } & \text { Dendritic cells } \\ \text { DKA } & \text { Diabeticketoacidosis } \\ \text { ER } & \text { Endoplasmic reticulum } \\ \text { FADH2 } & \text { Flavin adenine dinucleotide } \\ \text { FFAs } & \text { Free fatty acids } \\ \text { FOS } & \text { Fructo-oligosaccharide } \\ \text { Fox } & \text { Forkhead box } \\ \text { GATA3 } & \text { GATA binding protein 3 } \\ \text { GC } & \text { Guanine-plus-cytosine } \\ \text { GOS } & \text { Galacto-oligosaccharide } \\ \text { GPCRs } & \text { G-protein coupled receptors } \\ & \end{array}$




\begin{tabular}{|c|c|}
\hline GR & Glucocorticoid receptor \\
\hline HDACs & Histone deacetylases \\
\hline HEK293 & Human embryonic kidney 293 \\
\hline HRB & Human-Residential Bifidobacteria \\
\hline HT-29 & Colon adenocarcinoma cell line \\
\hline IL & Interleukin \\
\hline IFN & Interferon \\
\hline $\mathrm{IkB}$ & Inhibitor of kappa B \\
\hline IKK & Kappa B kinase \\
\hline ILA & Indole-3-lactic acid \\
\hline ILC2s & Group 2 Innate lymphoid cells \\
\hline IRAK-2 & IL-1 receptor-associated kinase 2 \\
\hline JNK & c-JUN NH2-terminal kinase \\
\hline Kac & Histone/lysineacetylation \\
\hline Kbhb & $\beta$-hydroxybutyrylation \\
\hline KBs & Ketone bodies \\
\hline KD & Ketogenic diet \\
\hline Kme & Histonemethylation \\
\hline LAB & Lactic acid bacteria \\
\hline LCDs & Low carbohydrate diets \\
\hline $\mathrm{LDH}$ & Lactate dehydrogenase \\
\hline LPS & Lipopolysaccharide \\
\hline MCTI1 & Monocarboxylate transporter 1 \\
\hline MED & Mediterranean diet \\
\hline $\operatorname{miR}$ & MicroRNA \\
\hline $\mathrm{MnSOD}$ & Manganese superoxide dismutase \\
\hline Mt2 & Metallothionein 2A \\
\hline MUFA & Monounsaturated fatty acid \\
\hline $\mathrm{NADH}$ & Nicotinamide adenine dinucleotide \\
\hline NAPA & Nitrate reductase catalytic subunit \\
\hline NF- $k \mathrm{~B}$ & Nuclear factor- $\mathrm{kB}$ \\
\hline NLRP3 & $\begin{array}{l}\text { Leucine-rich-containing family, pyrin } \\
\text { domain-containing-3 }\end{array}$ \\
\hline OMVs & Nanosized outer membrane vesicles \\
\hline ORMDL3 & ORM (yeast)-Like protein isoform 3 \\
\hline PSA & Polysaccharide A \\
\hline $\operatorname{PPAR} \gamma$ & Peroxisome proliferator-activated receptor gamma \\
\hline PUFA & Polyunsaturated fatty acid \\
\hline P38 MAPK & p38 mitogen-activated protein kinase \\
\hline RelA & Relaxedaspartate-auxotrophic \\
\hline RCTs & Randomized controlled trials \\
\hline ROS & Reactive oxygen species \\
\hline SAT & Saturated fatty acid \\
\hline SCFAs & Short-chain fatty acids \\
\hline SERCA & Sarco-endoplasmic reticulum $\mathrm{Ca}^{2+}$ pump \\
\hline SIgA & Secretory immunoglobulin A \\
\hline Smad & Deca-pentaplegic homolog \\
\hline ST2 & Stimulation-expressed gene 2 \\
\hline TCA & Tricarboxylic acid \\
\hline TGF & Transforming growth factor \\
\hline TLR & Toll like receptor \\
\hline TNF- $\alpha$ & Tumor necrosis factor \\
\hline TRAF & Tumor receptor associated factor \\
\hline $\mathrm{T}_{\text {regs }}$ & Regulatory T cells \\
\hline TSLP & Thymic stromal lymphopoietin \\
\hline UPR & Unfolded-protein response \\
\hline VLCD & Very low-calorie diet \\
\hline VLCKD & Very low-calorie ketogenic diet \\
\hline
\end{tabular}




\section{References}

1. Oh, R.; Uppaluri, K.R. Low Carbohydrate Diet; StatPearls: Treasure Island, FL, USA, 2020.

2. Kossoff, E.H.; Dorward, J.L. The modified Atkins diet. Epilepsia 2008, 49, 37-41. [CrossRef]

3. Feinman, R.D.; Pogozelski, W.K.; Astrup, A.; Bernstein, R.K.; Fine, E.J.; Westman, E.C.; Accurso, A.; Frassetto, L.; Gower, B.A.; McFarlane, S.I.; et al. Dietary carbohydrate restriction as the first approach in diabetes management: Critical review and evidence base. Nutrition 2015, 31, 1-13. [CrossRef]

4. Kosinski, C.; Jornayvaz, F.R. Effects of ketogenic diets on cardiovascular risk factors: Evidence from animal and human studies. Nutrients 2017, 9, 517. [CrossRef]

5. Ting, R.; Dugré, N.; Allan, G.M.; Lindblad, A.J. Ketogenic diet for weight loss. Can. Fam. Physician 2018, $64,906$.

6. Shingler, E.; Perry, R.; Mitchell, A.; England, C.; Perks, C.; Herbert, G.; Ness, A.; Atkinson, C. Dietary restriction during the treatment of cancer: Results of a systematic scoping review. BMC Cancer 2019, $19,811$. [CrossRef]

7. Bolla, A.M.; Caretto, A.; Laurenzi, A.; Scavini, M.; Piemonti, L. Low-carb and ketogenic diets in type 1 and type 2 diabetes. Nutrients 2019, 11, 962. [CrossRef]

8. Włodarek, D. Role of ketogenic diets in neurodegenerative diseases (Alzheimer's disease and Parkinson's disease). Nutrients 2019, 11, 169. [CrossRef]

9. Paoli, A.; Mancin, L.; Bianco, A.; Thomas, E.; Mota, J.F.; Piccini, F. Ketogenic diet and microbiota: Friends or enemies? Genes 2019, 10, 534. [CrossRef]

10. Rinninella, E.; Cintoni, M.; Raoul, P.; Ianiro, G.; Laterza, L.; Lopetuso, L.R.; Ponziani, F.R.; Gasbarrini, A.; Mele, M.C. Gut microbiota during dietary restrictions: New insights in non-communicable diseases. Microorganisms 2020, 8, 1140. [CrossRef]

11. Cabrera-Mulero, A.; Tinahones, A.; Bandera, B.; Moreno-Indias, I.; Macías-González, M.; Tinahones, F.J. Keto microbiota: A powerful contributor to host disease recovery. Rev. Endocr. Metab. Disord. 2019, 20, 415-425. [CrossRef]

12. Thursby, E.; Juge, N. Introduction to the human gut microbiota. Biochem. J. 2017, 474, 1823-1836. [CrossRef]

13. Alsharairi, N.A. The infant gut microbiota and risk of asthma: The effect of maternal nutrition during pregnancy and lactation. Microorganisms 2020, 8, 1119. [CrossRef]

14. Shilpa, J.; Mohan, V. Ketogenic diets: Boon or bane? Indian J. Med. Res. 2018, 148, 251-253.

15. Masood, W.; Uppaluri, K.R. Ketogenic Diet.; StatPearls: Treasure Island, FL, USA, 2020.

16. Batch, J.T.; Lamsal, S.P.; Adkins, M.; Sultan, S.; Ramirez, M.N. Advantages and disadvantages of the ketogenic diet. A review article. Cureuz 2020, 12, e9639.

17. Holscher, H.D. Dietary fiber and prebiotics and the gastrointestinal microbiota. Gut Microbes 2017, 8, 172-184. [CrossRef]

18. Myhrstad, M.C.W.; Tunsjø, H.; Charnock, C.; Telle-Hansen, V.H. Dietary fiber, gut microbiota, and metabolic regulation-current status in human randomized trials. Nutrients 2020, 12, 859. [CrossRef]

19. Wolters, M.; Ahrens, J.; Romaní-Pérez, M.; Watkins, W.; Sanz, Y.; Benítez-Páez, A.; Stanton, C.; Günther, K. Dietary fat, the gut microbiota, and metabolic health-A systematic review conducted within the MyNewGut project. Clin. Nutr. 2019, 38, 2504-2520. [CrossRef]

20. Longo, R.; Peri, C.; Cricrì, D.; Coppi, L.; Caruso, D.; Mitro, N.; De Fabiani, E.; Crestani, M. Ketogenic diet: A new light shining on old but gold biochemistry. Nutrients 2019, 11, 2497. [CrossRef]

21. Dhatariya, K. Blood Ketones: Measurement, interpretation, limitations, and utility in the management of diabetic ketoacidosis. Rev. Diabet. Stud. 2019, 13, 217-225. [CrossRef]

22. Jesenak, M.; Zelieskova, M.; Babusikova, E. Oxidative stress and bronchial asthma in children-causes or consequences? Front. Pediatr. 2017, 5, 162. [CrossRef]

23. Youm, Y.H.; Nguyen, K.Y.; Grant, R.W.; Goldberg, E.L.; Bodogai, M.; Kim, D.; D'Agostino, D.; Planavsky, N.; Lupfer, C.; Kanneganti, T.D.; et al. The ketone metabolite $\beta$-hydroxybutyrate blocks NLRP3 inflammasome-mediated inflammatory disease. Nat. Med. 2015, 21, 263-269. [CrossRef] [PubMed]

24. Puchalska, P.; Crawford, P.A. Multi-dimensional roles of ketone bodies in fuel metabolism, signaling, and therapeutics. Cell Metab. 2017, 25, 262-284. [CrossRef] 
25. Arrieta, M.C.; Stiemsma, L.T.; Dimitriu, P.A.; Thorson, L.; Russell, S.; Yurist-Doutsch, S.; Kuzeljevic, B.; Gold, M.J.; Britton, H.M.; Lefevre, D.L.; et al. Early infancy microbial and metabolic alterations affect risk of childhood asthma. Sci. Transl. Med. 2015, 7, 307ra152. [CrossRef] [PubMed]

26. Hilty, M.; Burke, C.; Pedro, H.; Cardenas, P.; Bush, A.; Bossley, C.; Davies, J.; Ervine, A.; Poulter, L.; Pachter, L.; et al. Disordered microbial communities in asthmatic airways. PLoS ONE 2010, 5, e8578. [CrossRef] [PubMed]

27. Hufnagl, K.; Pali-Schöll, I.; Roth-Walter, F.; Jensen-Jarolim, E. Dysbiosis of the gut and lung microbiome has a role in asthma. Semin. Immunopathol. 2020, 42, 75-93. [CrossRef] [PubMed]

28. Lee, $\mathrm{H}$. The interaction between gut microbiome and nutrients on development of human disease through epigenetic mechanisms. Genom. Inform. 2019, 17, e24. [CrossRef]

29. D'Aquila, P.; Carelli, L.L.; De Rango, F.; Passarino, G.; Bellizzi, D. Gut microbiota as important mediator between diet and DNA methylation and histone modifications in the host. Nutrients 2020, 12, 597. [CrossRef]

30. Harvey, K.L.; Holcomb, L.E.; Kolwicz, S.C., Jr. Ketogenic diets and exercise performance. Nutrients 2019, 11, 2296. [CrossRef]

31. Wallace, D.C.; Fan, W.; Procaccio, V. Mitochondrial energetics and therapeutics. Annu. Rev. Pathol. 2010, 5, 297-348. [CrossRef]

32. Paoli, A.; Bosco, G.; Camporesi, E.M.; Mangar, D. Ketosis, ketogenic diet and food intake control: A complex relationship. Front. Psychol. 2015, 6, 27. [CrossRef]

33. Dhillon, K.K.; Gupta, S. Biochemistry, Ketogenesis; StatPearls: Treasure Island, FL, USA, 2019.

34. Zeng, Z.; Liu, F.; Li, S. Metabolic adaptations in pregnancy: A review. Ann. Nutr. Metab. 2017, 70, 59-65. [CrossRef] [PubMed]

35. Tzika, E.; Dreker, T.; Imhof, A. Epigenetics and metabolism in health and disease. Front. Genet. 2018, 9, 361. [CrossRef] [PubMed]

36. Prescott, S.; Saffery, R. The role of epigenetic dysregulation in the epidemic of allergic disease. Clin. Epigenet. 2011, 2, 223-232. [CrossRef] [PubMed]

37. De Planell-Saguer, M.; Lovinsky-Desir, S.; Miller, R.L. Epigenetic regulation: The interface between prenatal and early-life exposure and asthma susceptibility. Environ. Mol. Mutagenesis 2014, 55, 231-243. [CrossRef] [PubMed]

38. Hartwig, F.P.; Loret de Mola, C.; Davies, N.M.; Victora, C.G.; Relton, C.L. Breastfeeding effects on DNA methylation in the offspring: A systematic literature review. PLOS ONE 2017, 12, e0173070.

39. Salam, M.T.; Zhang, Y.; Begum, K. Epigenetics and childhood asthma: Current evidence and future research directions. Epigenomics 2012, 4, 415-429. [CrossRef]

40. Qi, C.; Xu, C.; Koppelman, G.H. The role of epigenetics in the development of childhood asthma. Expert Rev. Clin. Immunol. 2019, 15, 1287-1302. [CrossRef]

41. Newman, J.C.; Verdin, E. $\beta$-hydroxybutyrate: Much more than a metabolite. Diabetes Res. Clin. Pract. 2014, 106, 173-181. [CrossRef]

42. Sasaki, K.; Sasaki, D.; Hannya, A. In vitro human colonic microbiota utilises D- $\beta$-hydroxybutyrate to increase butyrogenesis. Sci. Rep. 2020, 10, 8516. [CrossRef]

43. Xie, Z.; Zhang, D.; Chung, D. Metabolic regulation of gene expression by histone lysine $\beta$-hydroxybutyrylation. Mol. Cell 2016, 62, 194-206. [CrossRef]

44. Fellows, R.; Varga-Weisz, P. Chromatin dynamics and histone modifications in intestinal microbiota-host crosstalk. Mol. Metab. 2020, 38, 100925. [CrossRef] [PubMed]

45. Ruan, H.; Crawford, P.A. Ketone bodies as epigenetic modifiers. Curr. Opin. Clin. Nutr. Metab. Care 2018, 21, 260-266. [CrossRef] [PubMed]

46. Dabek, A.; Wojtala, M.; Pirola, L.; Balcerczyk, A. Modulation of cellular biochemistry, epigenetics and metabolomics by ketone bodies. Implications of the ketogenic diet in the physiology of the organism and pathological states. Nutrients 2020, 12, 788. [CrossRef] [PubMed]

47. Shimazu, T.; Hirschey, M.D.; Newman, J.; He, W.; Shirakawa, K.; Le Moan, N.; Grueter, C.A.; Lim, H.; Saunders, L.R.; Stevens, R.D.; et al. Suppression of oxidative stress by $\beta$-hydroxybutyrate, an endogenous histone deacetylase inhibitor. Science 2013, 339, 211-214. [CrossRef]

48. Ono, J.G.; Worgall, T.S.; Worgall, S. 17q21 locus and ORMDL3: An increased risk for childhood asthma. Pediatr. Res. 2014, 75, 165-170. [CrossRef] 
49. Cantero-Recasens, G.; Fandos, C.; Rubio-Moscardo, F.; Valverde, M.A.; Vicente, R. The asthma-associated ORMDL3 gene product regulates endoplasmic reticulum-mediated calcium signaling and cellular stress. Hum. Mol. Genet. 2010, 19, 111-121. [CrossRef]

50. Miller, M.; Tam, A.B.; Cho, J.Y.; Doherty, T.A.; Pham, A.; Khorram, N.; Rosenthal, P.; Mueller, J.L.; Hoffman, H.M.; Suzukawa, M.; et al. ORMDL3 is an inducible lung epithelial gene regulating metalloproteases, chemokines, OAS, and ATF6. Proc. Natl. Acad. Sci. USA 2012, 109, 16648-16653. [CrossRef]

51. Bae, H.R.; Kim, D.H.; Park, M.H.; Lee, B.; Kim, M.J.; Lee, E.K.; Chung, K.W.; Kim, S.M.; Im, D.S.; Chung, H.Y. $\beta$-Hydroxybutyrate suppresses inflammasome formation by ameliorating endoplasmic reticulum stress via AMPK activation. Oncotarget 2016, 7, 66444-66454. [CrossRef]

52. Krauss-Etschmann, S.; Meyer, K.F.; Dehmel, S.; Hylkema, M.N. Inter- and transgenerational epigenetic inheritance: Evidence in asthma and COPD? Clin. Epigenet. 2015, 7, 53. [CrossRef]

53. Indrio, F.; Martini, S.; Francavilla, R.; Corvaglia, L.; Cristofori, F.; Mastrolia, S.A.; Neu, J.; Rautava, S.; Spena, G.R.; Raimondi, F.; et al. Epigenetic matters: The link between early nutrition, microbiome, and long-term health development. Front. Pediatr. 2017, 5, 178. [CrossRef]

54. Miro-Blanch, J.; Yanes, O. Epigenetic regulation at the interplay between gut microbiota and host metabolism. Front. Genet. 2019, 10, 638. [CrossRef] [PubMed]

55. García-Mantrana, I.; Selma-Royo, M.; González, S.; Parra-Llorca, A.; Martínez-Costa, C.; Collado, M.C. Distinct maternal microbiota clusters are associated with diet during pregnancy: Impact on neonatal microbiota and infant growth during the first 18 months of life. Gut Microbes 2020, 11, 962-978. [CrossRef] [PubMed]

56. Maher, S.E.; O’Brien, E.C.; Moore, R.L.; Byrne, D.F.; Geraghty, A.A.; Saldova, R.; Murphy, E.F.; Van Sinderen, D.; Cotter, P.D.; McAuliffe, F.M. The association between the maternal diet and the maternal and infant gut microbiome: A systematic review. Br. J. Nutr. 2020, 4, 1-29. [CrossRef] [PubMed]

57. Roytio, H.; Mokkala, K.; Vahlberg, T.; Laitinen, K. Dietary intake of fat and fibre according to reference values relates to higher gut microbiota richness in overweight pregnant women. Br. J. Nutr. 2017, 118, 343-352. [CrossRef]

58. Barrett, H.L.; Gomez-Arango, L.F.; Wilkinson, S.A.; McIntyre, H.D.; Callaway, L.K.; Morrison, M.; Nitert, M.D. A Vegetarian diet is a major determinant of gut microbiota composition in early pregnancy. Nutrients 2018, 10, 890. [CrossRef]

59. Lundgrenm, S.N.; Madan, J.C.; Emond, J.A.; Morrison, H.G.; Christensen, B.C.; Karagas, M.R.; Hoen, A.G. Maternal diet during pregnancy is related with the infant stool microbiome in a delivery mode-dependent manner. Microbiome 2018, 6, 109. [CrossRef]

60. Simione, M.; Harshman, S.G.; Castro, I.; Linnemann, R.; Roche, B.; Ajami, N.J.; Petrosino, J.F.; Raspini, B.; Portale, S.; Camargo Jr, C.A.; et al. Maternal fish consumption in pregnancy is associated with a Bifidobacteriumdominant microbiome profile in infants. Curr. Dev. Nutr. 2020, 4, nzz133. [CrossRef]

61. Chu, D.M.; Antony, K.M.; Ma, J.; Prince, A.L.; Showalter, L.; Moller, M.; Aagaard, K.M. The early infant gut microbiome varies in association with a maternal high-fat diet. Genome Med. 2016, 8, 77. [CrossRef]

62. Fernández, L.; Langa, S.; Martín, V.; Maldonado, A.; Jiménez, E.; Martín, R.; Rodríguez, J.M. The human milk microbiota: Origin and potential roles in health and disease. Pharmacol. Res. 2013, 69, 1-10. [CrossRef]

63. Rodriguez, J.M. The origin of human milk bacteria: Is there a bacterial entero-mammary pathway during late pregnancy and lactation? Adv. Nutr. Int. Rev. J. 2014, 5, 779-784. [CrossRef]

64. Stinson, L.F.; Gay, M.C.L.; Koleva, P.T.; Eggesbø, M.; Johnson, C.C.; Wegienka, G.; du Toit, E.; Shimojo, N.; Munblit, D.; Campbell, D.E.; et al. Human milk from atopic mothers has lower levels of short chain fatty acids. Front. Immunol. 2020, 11, 1427. [CrossRef] [PubMed]

65. Ríos-Covián, D.; Ruas-Madiedo, P.; Margolles, A.; Gueimonde, M.; de Los Reyes-Gavilán, C.G.; Salazar, N. Intestinal short chain fatty acids and their link with diet and human health. Front. Microbiol. 2016, 7, 185. [CrossRef] [PubMed]

66. Louis, P.; Flint, H.J. Formation of propionate and butyrate by the human colonic microbiota. Environ. Microbiol. 2017, 19, 29-41. [CrossRef] [PubMed]

67. Milani, C.; Duranti, S.; Bottacin, F.; Casey, E.; Turroni, F.; Mahony, J.; Belzer, C.; Palacio, S.D.; Montes, S.A.; Mancabelli, L.; et al. The first microbial colonizers of the human Gut: Composition, activities, and health implications of the infant gut microbiota. Microbiol. Mol. Biol. Rev. 2017, 81, e00036-17. [CrossRef] 
68. Bridgman, S.L.; Azad, M.B.; Field, C.J.; Haqq, A.M.; Becker, A.B.; Mandhane, P.J.; Subbarao, P.; Turvey, S.E.; Sears, M.R.; Scott, J.A.; et al. Fecal short-chain fatty acid variations by breastfeeding status in infants at 4 months: Differences in relative versus absolute concentrations. Front. Nutr. 2017, 4, 11. [CrossRef]

69. McOrist, A.L.; Miller, R.B.; Bird, A.R.; Keogh, J.B.; Noakes, M.; Topping, D.L.; Conlon, M.A. Fecal butyrate levels vary widely among individuals but are usually increased by a diet high in resistant starch. J. Nutr. 2011, 141, 883-889. [CrossRef]

70. Smilowitz, J.T.; O'Sullivan, A.; Barile, D.; German, J.B.; Lönnerdal, B.; Slupsky, C.M. The human milk metabolome reveals diverse oligosaccharide profiles. J. Nutr. 2013, 143, 1709-1718. [CrossRef]

71. Wu, J.; Domellöf, M.; Zivkovic, A.M.; Larsson, G.; Öhman, A.; Nording, M.L. NMR-based metabolite profiling of human milk: A pilot study of methods for investigating compositional changes during lactation. Biochem. Biophys. Res. Commun. 2016, 469, 626-632. [CrossRef]

72. Flint, H.J.; Duncan, S.H.; Scott, K.P.; Louis, P. Links between diet, gut microbiota composition and gut metabolism. Proc. Nutr. Soc. 2015, 74, 13-22. [CrossRef]

73. Vacca, M.; Celano, G.; Calabrese, F.M.; Portincasa, P.; Gobbetti, M.; De Angelis, M. The controversial role of human gut Lachnospiraceae. Microorganisms 2020, 8, 573. [CrossRef]

74. Oliphant, K.; Allen-Vercoe, E. Macronutrient metabolism by the human gut microbiome: Major fermentation by-products and their impact on host health. Microbiome 2019, 7, 91. [CrossRef]

75. Barcik, W.; Boutin, R.C.T.; Sokolowska, M.; Finlay, B.B. The role of lung and gut microbiota in the pathology of asthma. Immunity 2020, 52, 241-255. [CrossRef] [PubMed]

76. Smith, P.M.; Howitt, M.R.; Panikov, N.; Michaud, M.; Gallini, C.A.; Bohlooly, Y.M.; Glickman, J.N.; Garrett, W.S. The microbial metabolites, short-chain fatty acids, regulate colonic Treg cell homeostasis. Science 2013, 341, 569-573. [CrossRef]

77. Steinmeyer, S.; Lee, K.; Jayaraman, A.; Alaniz, R.C. Microbiota metabolite regulation of host immune homeostasis: A mechanistic missing link. Curr. Allergy Asthma Rep. 2015, 15, 24. [CrossRef] [PubMed]

78. Zhao, S.; Wang, C. Regulatory T cells and asthma. J. Zhejiang Univ. Sci. B 2018, 19, 663-673. [CrossRef] [PubMed]

79. Kespohl, M.; Vachharajani, N.; Luu, M.; Harb, H.; Pautz, S.; Wolff, S.; Sillner, N.; Walker, A.; Schmitt-Kopplin, P.; Boettger, T.; et al. The microbial metabolite Butyrate induces expression of Th1- associated factors in CD4 ${ }^{+}$ T Cells. Front. Immunol. 2017, 8, 1036. [CrossRef]

80. Liu, H.; Wang, J.; He, T.; Becker, S.; Zhang, G.; Li, D.; Ma, X. Butyrate: A double-edged sword for health? Adv. Nutr. 2018, 9, 21-29. [CrossRef]

81. Gray, L.E.; O'Hely, M.; Ranganathan, S.; Sly, P.D.; Vuillermin, P. The maternal diet, gut bacteria, and bacterial metabolites during pregnancy influence offspring asthma. Front. Immunol. 2017, 8, 365. [CrossRef]

82. Lewis, G.; Wang, B.; Jahani, P.S. Dietary fiber-induced microbial short chain fatty acids suppress ILC2-dependent airway inflammation. Front. Immunol. 2019, 10, 2051. [CrossRef]

83. Janssen-Heininger, Y.M.W.; Poynter, M.E.; Aesif, S.W.; Pantano, C.; Ather, J.L.; Reynaert, N.L.; Ckless, K.; Anathy, V.; van der Velden, J.; Irvin, C.G.; et al. Nuclear factor kB, airway epithelium, and asthma: Avenues for redox control. Proc. Am. Thorac. Soc. 2009, 6, 249-255. [CrossRef]

84. Edwards, M.R.; Bartlett, N.W.; Clarke, D.; Birrell, M.; Belvisi, M.; Johnston, S.L. Targeting the NF-kappaB pathway in asthma and chronic obstructive pulmonary disease. Pharmacol. Ther. 2009, 121, 1-13. [CrossRef] [PubMed]

85. McKenzie, A.N.J. Type-2 innate lymphoid cells in asthma and allergy. Ann. Am. Thorac. Soc. 2014, 11, S263-S270. [CrossRef] [PubMed]

86. Stier, M.T.; Peebles, R.S. Innate lymphoid cells and allergic disease. Ann. Allergy Asthma Immunol. 2017, 119, 480-488. [CrossRef] [PubMed]

87. Cavaleri, F.; Bashar, E. Potential synergies of $\beta$-hydroxybutyrate and butyrate on the modulation of metabolism, inflammation, cognition, and general health. J. Nutr. Metab. 2018, 2018, 7195760. [CrossRef]

88. Brouns, F. Overweight and diabetes prevention: Is a low-carbohydrate-high-fat diet recommendable? Eur. J. Nutr. 2018, 57, 1301-1312. [CrossRef]

89. Chiu, C.; Cheng, M.; Chiang, M.; Kuo, Y.; Tsai, M.; Chiu, C.; Lin, G. Gut microbial-derived butyrate is inversely associated with IgE responses to allergens in childhood asthma. Pediatr. Allergy Immunol. 2019, 30, 689-697. [CrossRef] 
90. Thorburn, A.N.; McKenzie, C.I.; Shen, S.; Stanley, D.; Macia, L.; Mason, L.J.; Roberts, L.K.; Wong, C.H.Y.; Shim, R.; Robert, R.; et al. Evidence that asthma is a developmental origin disease influenced by maternal diet and bacterial metabolites. Nat. Commun. 2015, 6, 7320. [CrossRef]

91. Lima, J.J.; Mohapatra, S.; Feng, H.; Lockey, R.; Jena, P.K.; Castro, M.; Irvin, C.; Johnson, J.A.; Wang, J.; Sylvester, J.E. A polymorphism in the NPPA gene associates with asthma. Clin. Exp. Allergy. 2008, 38, 1117-1123. [CrossRef]

92. Lee-Sarwar, K.A.; Kelly, R.S.; Lasky-Su, J.; Zeiger, R.S.; O'Connor, G.T.; Sandel, M.T.; Bacharier, L.B.; Beigelman, A.; Rifas-Shiman, S.L.; Carey, V.J.; et al. Fecal short-chain fatty acids in pregnancy and offspring asthma and allergic outcomes. J. Allergy Clin. Immunol. Pract. 2020, 8, 1100-1102.e13. [CrossRef]

93. Akdis, M.; Aab, A.; Altunbulakli, C.; Azkur, K.; Costa, R.A.; Crameri, R.; Duan, S.; Eiwegger, T.; Eljaszewicz, A.; Ferstl, R.; et al. Interleukins (from IL-1 to IL-38), interferons, transforming growth factor $\beta$, and TNF- $\alpha$ : Receptors, functions, and roles in diseases. J. Allergy Clin. Immunol. 2016, 138, 984-1010. [CrossRef]

94. Rajilić-Stojanović, M.; de Vos, W.M. The first 1000 cultured species of the human gastrointestinal microbiota. FEMS Microbiol. Rev. 2014, 38, 996-1047. [CrossRef] [PubMed]

95. Wong, C.B.; Odamaki, T.; Xiao, J. Insights into the reason of Human-Residential Bifidobacteria (HRB) being the natural inhabitants of the human gut and their potential health-promoting benefits. FEMS Microbiol. Rev. 2020, 44, 369-385. [CrossRef] [PubMed]

96. Singh, R.K.; Chang, H.; Yan, D.; Lee, K.M.; Ucmak, D.; Wong, K.; Abrouk, M.; Farahnik, B.; Nakamura, M.; Zhu, T.H.; et al. Influence of diet on the gut microbiome and implications for human health. J. Transl. Med. 2017, 15, 73. [CrossRef] [PubMed]

97. Stokholm, J.; Blaser, M.J.; Thorsen, J.; Rasmussen, M.A.; Waage, J.; Vinding, R.K.; Schoos, A.M.; Kunøe, A.; Fink, N.R.; Chawes, B.L.; et al. Maturation of the gut microbiome and risk of asthma in childhood. Nat. Commun. 2018, 9, 141. [CrossRef] [PubMed]

98. Ehrlich, A.M.; Henrick, B.; Pacheco, A.; Taft, D.; Xu, G.; Huda, N.; Lozada-Contreras, M.; Goodson, M.; Slupsky, C.; Mills, D.; et al. Bifidobacterium grown on human milk oligosaccharides produce tryptophan metabolite Indole-3-lactic acid that significantly decreases inflammation in intestinal cells in vitro. FASEB 2018, 32, IB359.

99. Di Meng, D.; Sommella, E.; Salviati, E.; Campiglia, P.; Ganguli, K.; Djebali, K.; Zhu, W.; Walker, W.A. Indole-3-lactic acid, a metabolite of tryptophan, secreted by Bifidobacterium longum subspecies infantis is anti-inflammatory in the immature intestine. Pediatr. Res. 2020, 88, 209-217. [CrossRef]

100. Di Meng, D.; Zhu, W.; Ganguli, K.; Shi, H.N.; Walker, W.A. Anti-inflammatory effects of Bifidobacterium longumsubspinfantis secretions on fetal human enterocytes are mediated by TLR-4 receptors. Am. J. Physiol. Gastrointest. Liver Physiol. 2016, 311, G744-G753. [CrossRef]

101. Balaci, L.; Spada, M.C.; Olla, N.; Sole, G.; Loddo, L.; Anedda, F.; Naitza, S.; Zuncheddu, M.A.; Maschio, A.; Altea, D.; et al. IRAK-M is involved in the pathogenesis of early-onset persistent asthma. Am. J. Hum. Genet. 2007, 80, 1103-1114. [CrossRef]

102. Smilowitz, J.T.; Moya, J.; Breck, M.A. Safety and tolerability of Bifidobacterium longum subspecies infantis EVC001 supplementation in healthy term breastfed infants: A phase I clinical trial. BMC Pediatr. 2017, 17, 180.

103. Henrick, B.M.; Chew, S.; Casaburi, G.; Brown, H.K.; Frese, S.A.; Zhou, Y.; Underwood, M.A.; Smilowitz, J.T. Colonization by B. infantis EVC001 modulates enteric inflammation in exclusively breastfed infants. Pediatric Res. 2019, 86, 749-757. [CrossRef]

104. De Andrés, J.; Manzano, S.; García, C.; Rodríguez, J.M.; Espinosa-Martos, I.; Jiménez, E. Modulatory effect of three probiotic strains on infants' gut microbial composition and immunological parameters on a placebo-controlled, double-blind, randomised study. Benef. Microbes 2018, 9, 573-584. [CrossRef] [PubMed]

105. Sakurai, T.; Odamaki, T.; Xiao, J. Production of indole-3-lactic acid by Bifidobacterium strains isolated from human infants. Microorganisms 2019, 7, 340. [CrossRef] [PubMed]

106. Laursen, M.F.; Sakanaka, M.; von Burg, N.; Andersen, D.; Mörbe, U.; Rivollier, A.; Pekmez, C.T.; Moll, J.M.; Michaelsen, K.F.; Mølgaard, C.; et al. Breastmilk-promoted bifidobacteria produce aromatic lactic acids in the infant gut. BioRxiv 2020. [CrossRef]

107. Ménard, C.; Candalh, J.C.; Bambou, C.; Terpend, K.; Cerf-Bensussan, N.; Heyman, M. Lactic acid bacteria secrete metabolites retaining anti-inflammatory properties after intestinal transport. Gut 2004, 53, 821-828. [CrossRef] 
108. Riedel, C.U.; Foata, F.; Philippe, D.; Adolfsson, O.; Eikmanns, B.; Blum, S. Anti-inflammatory effects of bifidobacteria by inhibition of LPS-induced NF-kB activation. World J. Gastroenterol. 2006, 12, 3729-3735. [CrossRef]

109. Khokhlova, E.V.; Smeianov, V.V.; Efimov, B.A.; Kafarskaia, L.I.; Pavlova, S.I.; Shkoporov, A.N. Anti-inflammatory properties of intestinal Bifidobacterium strains isolated from healthy infants. Microbiol. Immunol. 2012, 56, 27-39. [CrossRef]

110. Wu, B.; Yang, Y.; Xu, X.; Wang, W. Effects of Bifidobacterium supplementation on intestinal microbiota composition and the immune response in healthy infants. World J. Pediatr. 2016, 12, 177-182. [CrossRef]

111. Wong, C.B.; Iwabuchi, N.; Xiao, J. Exploring the science behind Bifidobacterium breve M-16V in infant health. Nutrients 2019, 11, 1724. [CrossRef]

112. Cukrowska, B.; Bierła, J.B.; Zakrzewska, M. The relationship between the infant gut microbiota and allergy. The role of Bifidobacterium breve and prebiotic oligosaccharides in the activation of anti-allergic mechanisms in early life. Nutrients 2020, 12, 946. [CrossRef]

113. Del Giudice, M.M.; Indolfi, C.; Capasso, M. Bifidobacterium mixture (B longum BB536, B infantis M-63, B breve M-16V) treatment in children with seasonal allergic rhinitis and intermittent asthma. Ital. J. Pediatr. 2017, 43, 25. [CrossRef]

114. Enomoto, T.; Sowa, M.; Nishimori, K.; Shimazu, S.; Yoshida, A.; Yamada, K.; Furukawa, F.; Nakagawa, T.; Yanagisawa, N.; Iwabuchi, N.; et al. Effects of bifidobacterial supplementation to pregnant women and infants in the prevention of allergy development in infants and on fecal microbiota. Allergol. Int. 2014, 63, 575-585. [CrossRef] [PubMed]

115. Matsuyama, M.; Morrison, M.; Lê Cao, K.; Pruilh, S.; Davies, P.S.W.; Wall, C.; Lovell, A.; Hill, R.J. Dietary intake influences gut microbiota development of healthy Australian children from the age of one to two years. Sci. Rep. 2019, 9, 12476. [CrossRef]

116. Fujii, T.; Ohtsuka, Y.; Lee, T.; Kudo, T.; Shoji, H.; Sato, H.; Nagata, S.; Shimizu, T.; Yamashiro, Y. Bifidobacterium breve enhances transforming growth factor beta1signaling by regulating smad7 expression in preterm infants. J. Pediatr. Gastroenterol. Nutr. 2006, 43, 83-88. [CrossRef] [PubMed]

117. Huang, H.; Lu, H.; Liang, L.; Zhi, Y.; Huo, B.; Wu, L.; Xu, L.; Shen, Z. MicroRNA-744 inhibits proliferation of bronchial epithelial cells by regulating smad3 pathway via targeting transforming growth factor- $\beta 1$ (TGF- $\beta 1$ ) in severe asthma. Med. Sci. Monit. 2019, 25, 2159-2168. [CrossRef] [PubMed]

118. Mayo, B.; van Sinderen, D.; Ventura, M. Genome analysis of food grade lactic acid-producing bacteria: From basics to applications. Curr. Genom. 2008, 9, 169-183. [CrossRef]

119. Bergström, A.; Skov, T.H.; Bahl, M.I.; Roager, H.M.; Christensen, L.B.; Ejlerskov, K.T.; Mølgaard, C.; Michaelsen, K.F.; Licht, T.R. Establishment of intestinal microbiota during early life: A longitudinal, explorative study of a large cohort of Danish infants. Appl. Environ. Microbiol. 2014, 80, 2889-2900. [CrossRef]

120. Vitetta, L.; Coulson, S.; Thomsen, M.; Nguyen, T.; Hall, S. Probiotics, D-Lactic acidosis, oxidative stress and strain specificity. Gut Microbes 2017, 8, 311-322. [CrossRef]

121. Johansson, M.A.; Sjögren, Y.M.; Persson, J.-O.; Nilsson, C.; Sverremark- Ekström, E. Early colonization with a group of Lactobacilli decreases the risk for allergy at five years of age despite allergic heredity. PLoS ONE 2011, 6, e23031. [CrossRef]

122. Koleva, P.T.; Tun, H.M.; Konya, T.; Guttman, D.S.; Becker, A.B.; Mandhane, P.J.; Turvey, S.E.; Subbarao, P.; Sears, M.R.; Scott, J.A.; et al. Sex-specific impact of asthma during pregnancy on infant gut microbiota. Eur. Respir. J. 2017, 50, 1700280. [CrossRef]

123. Jamyuang, C.; Phoonlapdacha, P.; Chongviriyaphan, N.; Chanput, W.; Nitisinprasert, S.; Nakphaichit, M. Characterization and probiotic properties of Lactobacilli from human breast milk. 3 Biotech 2019, 9, 398. [CrossRef]

124. Kook, S.; Chung, E.; Lee, Y.; Lee, D.; Kim, S. Isolation and characterization of five novel probiotic strains from Korean infant and children faeces. PLoS ONE 2019, 14, e223913. [CrossRef]

125. Oh, N.S.; Joung, J.Y.; Lee, J.Y.; Kim, Y. Probiotic and anti-inflammatory potential of Lactobacillus rhamnosus 4B15 and Lactobacillus gasseri 4M13 isolated from infant feces. PLoS ONE 2018, 13, e0192021. [CrossRef] [PubMed] 
126. Li, X.; Hu, D.; Tian, Y.; Song, Y.; Hou, Y.; Sun, L.; Zhang, Y.; Man, C.; Zhang, W.; Jiang, Y. Protective effects of a novel Lactobacillus rhamnosus strain with probiotic characteristics against lipopolysaccharide-induced intestinal inflammation in vitro and in vivo. Food Funct. 2020, 11, 5799-5814. [CrossRef] [PubMed]

127. Bermudez-Brito, M.; Muñoz-Quezada, S.; Gomez-Llorente, C.; Matencio, E.; Bernal, M.J.; Romero, F.; Gil, A. Human intestinal dendritic cells decrease cytokine release against Salmonella infection in the presence of Lactobacillus paracasei upon TLR activation. PLoS ONE 2012, 7, e43197. [CrossRef] [PubMed]

128. Johansson, M.A.; Saghafian-Hedengren, S.; Haileselassie, Y.; Roos, S.; Troye-Blomberg, M.; Nilsson, C.; Sverremark-Ekström, E. Early-life gut bacteria associate with IL-4-, IL-10- and IFN- $\gamma$ production at two years of age. PLoS ONE 2012, 7, e49315. [CrossRef] [PubMed]

129. Wexler, H.M. Bacteroides: The good, the bad, and the nitty-gritty. Clin. Microbiol. Rev. 2007, 20, 593-621. [CrossRef]

130. Mazmanian, S.K.; Liu, C.H.; Tzianabos, A.O.; Kasper, D.L. An immunomodulatory molecule of symbiotic bacteria directs maturation of the host immune system. Cell 2005, 122, 107-118. [CrossRef]

131. Hiippala, K.; Jouhten, H.; Ronkainen, A.; Hartikainen, A.; Kainulainen, V.; Jalanka, J.; Satokari, R. The potential of gut commensals in reinforcing intestinal barrier function and alleviating inflammation. Nutrients 2018, 10, 988. [CrossRef]

132. Round, J.L.; Mazmanian, S.K. Inducible Foxp3 ${ }^{+}$regulatory T-cell development by a commensal bacterium of the intestinal microbiota. Proc. Natl. Acad. Sci. USA 2010, 107, 12204-12209. [CrossRef]

133. Telesford, K.M.; Yan, W.; Ochoa-Reparaz, J.; Pant, A.; Kircher, C.; Christy, M.A.; Begum-Haque, S.; Kasper, D.L.; Kasper, L.H. A commensal symbiotic factor derived from Bacteroides fragilis promotes human CD39 ${ }^{+}$Foxp3 $^{+}$ T cells and Treg function. Gut Microbes 2015, 6, 234-242. [CrossRef]

134. Vael, C.; Nelen, V.; Verhulst, S.L. Early intestinal Bacteroides fragilis colonisation and development of asthma. BMC Pulm. Med. 2008, 8, 19. [CrossRef]

135. Sjogren, Y.M.; Tomicic, S.; Lundberg, A.; Böttcher, M.F.; Björkstén, B.; Sverremark-Ekström, E.; Jenmalm, M.C. Influence of early gut microbiota on the maturation of childhood mucosal and systemic immune responses. Clin. Exp. Allergy 2009, 39, 1842-1851. [CrossRef] [PubMed]

136. Durant, L.; Stentz, R.; Noble, A.; Brooks, J.; Gicheva, N.; Reddi, D.; O'Connor, M.J.; Hoyles, L.; McCartney, A.L.; Man, R.; et al. Bacteroides thetaiotaomicron-derived outer membrane vesicles promote regulatory dendritic cell responses in health but not in inflammatory bowel disease. Microbiome 2020, 8, 88. [CrossRef] [PubMed]

137. Kelly, D.; Campbell, J.I.; King, T.P.; Grant, G.; Jansson, E.A.; Coutts, A.G.; Pettersson, S.; Conway, S. Commensal anaerobic gut bacteria attenuate inflammation by regulating nuclear-cytoplasmic shuttling of PPAR- $\gamma$ and RelA. Nat. Immunol. 2004, 5, 104-112. [CrossRef] [PubMed]

138. Mishra, V.; Banga, J.; Silveyra, P. Oxidative stress and cellular pathways of asthma and inflammation: Therapeutic strategies and pharmacological targets. Pharmacol. Ther. 2018, 181, 169-182. [CrossRef] [PubMed]

139. Di Lorenzo, F.; Pither, M.D.; Martufi, M.; Scarinci, I.; Guzmán-Caldentey, J.; Łakomiec, E.; Jachymek, W.; Bruijns, S.C.M.; Santamaría, S.M.; Frick, J.; et al. Pairing Bacteroides vulgatus LPS structure with its immunomodulatory effects on human cellular models. ACS Cent. Sci. 2020, 6, 1602-1616. [CrossRef]

140. Lebreton, F.; Willems, R.J.L.; Gilmore, M.S. Enterococcus diversity, origins in nature, and gut colonization. In Enterococci: From Commensals to Leading Causes of Drug Resistant Infection; Gilmore, M.S., Clewell, D.B., Ike, Y., Shankar, N., Eds.; Massachusetts Eye and Ear Infirmary: Boston, MA, USA, 2014.

141. Gómez, M.; Moles, L.; Espinosa-Martos, I.; Bustos, G.; de Vos, W.M.; Fernández, L.; Rodríguez, J.M.; Fuentes, S.; Jiménez, E. Bacteriological and immunological profiling of meconium and fecal samples from preterm infants: A two-year follow-up study. Nutrients 2017, 9, 1293. [CrossRef]

142. Costabile, A.; Klinder, A.; Fava, F.; Napolitano, A.; Fogliano, V.; Leonard, C.; Gibson, G.R.; Tuohy, K.M. Whole-grain wheat breakfast cereal has a prebiotic effect on the human gut microbiota: A double-blind, placebo-controlled, crossover study. Br. J. Nutr. 2008, 99, 110-120. [CrossRef]

143. Bjorksten, B.; Sepp, E.; Julge, K.; Voor, T.; Mikelsaar, M. Allergy development and the intestinal microflora during the first year of life. J. Allergy Clin. Immunol. 2001, 108, 516-520. [CrossRef]

144. Wang, S.; Ng, L.H.M.; Chow, W.L.; Lee, Y.K. Infant intestinal Enterococcus faecalis down-regulates inflammatory responses in human intestinal cell lines. World J. Gastroenterol. 2008, 14, 1067-1076. [CrossRef]

145. Wang, S.; Hibberd, M.L.; Pettersson, S.; Lee, Y.K. Enterococcus faecalis from healthy infants modulates inflammation through MAPK signaling pathways. PLoS ONE 2014, 9, e97523. [CrossRef] [PubMed] 
146. Wang, J.; Faiz, A.; Ge, Q. Unique mechanisms of connective tissue growth factor regulation in airway smooth muscle in asthma: Relationship with airway remodeling. J. Cell. Mol. Med. 2018, 22, 2826-2837. [CrossRef]

147. Bhavsar, P.; Khorasani, N.; Hew, M.; Johnson, M.; Chung, K.F. Effect of p38 MAPK inhibition on corticosteroid suppression of cytokine release in severe asthma. Eur. Respir. J. 2010, 35, 750-756. [CrossRef]

148. Lea, S.; Li, J.; Plumb, J.; Gaffey, K.; Mason, S.; Gaskell, R.; Harbron, C.; Singh, D. P38 MAPK and glucocorticoid receptor crosstalk in bronchial epithelial cells. J. Mol. Med. 2020, 98, 361-374. [CrossRef]

149. Gao, X.; Zhi, X.; Li, H.; Klenk, H.; Li, W. Comparative genomics of the bacterial genus Streptococcus illuminates evolutionary implications of species groups. PLoS ONE. 2014, 9, e101229. [CrossRef]

150. Kozak, K.; Charbonneau, D.; Sanozky-Dawes, R.; Klaenhammer, T. Characterization of bacterial isolates from the microbiota of mothers' breast milk and their infants. Gut Microbes 2015, 6, 341-351. [CrossRef]

151. Solís, G.; delosReyes-Gavilan, C.G.; Fernández, N.; Margolles, A.; Gueimonde, M. Establishment and development of lactic acid bacteria and bifidobacteria microbiota in breast-milk and the infant gut. Anaerobe 2010, 16, 307-310. [CrossRef]

152. Hill, C.J.; Lynch, D.B.; Murphy, K.; Ulaszewska, M.; Jeffery, J.B.; O’Shea, C.A.; Watkins, C.; Dempsey, E.; Mattivi, F.; Tuohy, K.; et al. Evolution of gut microbiota composition from birth to 24 weeks in the INFANTMET Cohort. Microbiome 2017, 5, 4. [CrossRef]

153. Williams, J.E.; Carrothers, J.M.; Lackey, K.A.; Beatty, N.F.; Brooker, S.L.; Peterson, H.K.; Steinkamp, K.M.; York, M.A.; Shafii, B.; Price, W.J.; et al. Strong multivariate relations exist among milk, oral, and fecal microbiomes in mother-infant dyads during the first six months postpartum. J. Nutr. 2019, 149, 902-914. [CrossRef] [PubMed]

154. Tsunoda, Y.; Asahara, T.; Nomoto, K.; Yoshioka, Y.; Fukuma, E. Bacterial profile of infant feces associated with lactation infectious breasts. Pediatric Health Med. Ther. 2018, 9, 173-180. [CrossRef]

155. Park, Y.M.; Lee, S.Y.; Kang, M.J.; Kim, B.S.; Lee, M.J.; Jung, S.S.; Yoon, J.S.; Cho, H.J.; Lee, E.; Yang, S.I.; et al. Imbalance of gut Streptococcus, Clostridium, and Akkermansia determines the natural course of atopic dermatitis in infant. Allergy Asthma Immunol. Res. 2020, 12, 322-337. [CrossRef] [PubMed]

156. Béghin, L.; Tims, S.; Roelofs, M.; Rougé, C.; Oozeer, R.; Rakza, T.; Chirico, G.; Roeselers, G.; Knol, J.; Rozé, J.C.; et al. Fermented infant formula (with Bifidobacterium breve C50 and Streptococcus thermophilus O65) with prebiotic oligosaccharides is safe and modulates the gut microbiota towards a microbiota closer to that of breastfed infants. Clin. Nutr. 2020, S0261-5614, 30389-C7.

157. Lawley, B.; Otal, A.; Moloney-Geany, K.; Diana, A.; Houghton, L.; Heath, A.M.; Taylor, R.W.; Tannock, G.W. Fecal microbiotas of indonesian and New Zealand children differ in complexity and Bifidobacterial taxa during the first year of life. Appl. Environ. Microbiol. 2019, 85, e01105-19. [CrossRef] [PubMed]

158. Sagheddu, V.; Patrone, V.; Miragoli, F.; Puglisi, E.; Morelli, L. Infant early gut colonization by Lachnospiraceae: High frequency of Ruminococcusgnavus. Front. Pediatr. 2016, 4, 57. [CrossRef]

159. Sagheddu, V.; Patrone, V.; Miragoli, F.; Morelli, L. Abundance and diversity of hydrogenotrophic microorganisms in the infant gut before the weaning period assessed by denaturing gradient gel electrophoresis and quantitative PCR. Front. Nutr. 2017, 4, 29. [CrossRef]

160. Liu, C.; Finegold, S.M.; Song, Y.; Lawson, P.A. Reclassification of Clostridium coccoides, Ruminococcus hansenii, Ruminococcus hydrogenotrophicus, Ruminococcus luti, Ruminococcus productus and Ruminococcus schinkii as Blautia coccoides gen. nov., comb. nov., Blautia hansenii comb. nov., Blautia hydrogenotrophica comb. nov., Blautia luti comb. nov., Blautia producta comb. nov., Blautia schinkii comb. nov. and description of Blautia wexlerae sp. nov., isolated from human faeces. Int. J. Syst. Evol. Microbiol. 2008, 58, 1896-1902.

161. Lawson, P.A.; Finegold, S.M. Reclassification of Ruminococcusobeum as Blautiaobeum comb. nov. Int. J. Syst. Evol. Microbiol. 2015, 65, 789-793. [CrossRef]

162. Durack, J.; Kimes, N.E.; Lin, D.L.; Rauch, M.; McKean, M.; McCauley, K.; Panzer, A.R.; Mar, J.S.; Cabana, M.D.; Lynch, S.V. Delayed gut microbiota development in high-risk for asthma infants is temporarily modifiable by Lactobacillus supplementation. Nat. Commun. 2018, 9, 707. [CrossRef]

163. Benítez-Páez, A.; del Pugar, E.M.G.; López-Almela, I.; López-Almela, I.; Moya-Pérez, A.; Codoñer-Franch, P.; Sanz, Y. Depletion of Blautia species in the microbiota of obese children relates to intestinal inflammation and metabolic phenotype worsening. mSystems 2020, 5, e00857-19. [CrossRef]

164. Chua, H.; Chou, H.; Tung, Y.; Chiang, B.; Liao, C.; Liu, H.; Ni, Y. Intestinal dysbiosis featuring abundance of ruminococcus gnavus associates with allergic diseases in infants. Gastroenterology 2018, 154, 154-167. [CrossRef] 
165. West, C.E.; Rydén, P.; Lundin, D.; Engstrand, L.; Tulic, M.K.; Prescott, S.L. Gut microbiome and innate immune response patterns in IgE-associated eczema. Clin. Exp. Allergy 2015, 45, 1419-1429. [CrossRef] [PubMed]

166. Guo, P.; Zhang, K.; Ma, X.; He, P. Clostridium species as probiotics: Potentials and challenges. J. Anim. Sci. Biotechnol. 2020, 11, 24. [CrossRef] [PubMed]

167. Demirci, M.; Tokman, H.B.; Uysal, H.K.; Demiryas, S.; Karakullukcu, A.; Saribas, S.; Cokugras, H.; Kocazeybek, B.S. Reduced Akkermansia muciniphila and Faecalibacterium prausnitzii levels in the gut microbiota of children with allergic asthma. Allergol. Immunopathol. 2019, 47, 365-371. [CrossRef]

168. Ulluwishewa, D.; Anderson, R.C.; Young, W.; McNabb, W.C.; van Baarlen, P.; Moughan, P.J.; Wells, J.M.; Roy, N.C. Live Faecalibacterium prausnitzii in an apical anaerobic model of the intestinal epithelial barrier. Cell. Microbiol. 2015, 17, 226-240. [CrossRef] [PubMed]

169. Alameddine, J.; Godefroy, E.; Papargyris, L.; Sarrabayrouse, G.; Tabiasco, J.; Bridonneau, C.; Yazdanbakhsh, K.; Sokol, H.; Altare, F.; Jotereau, F. Faecalibacterium prausnitzii skews human DC to prime IL10-producing T cells through TLR2/6/JNK signaling and IL-10, IL-27, CD39, and IDO-1 induction. Front. Immunol. 2019, 10, 143. [CrossRef]

170. LeBlanc, J.G.; Chain, F.; Martín, R.; Bermúdez-Humarán, L.G.; Courau, S.; Langella, P. Beneficial effects on host energy metabolism of short-chain fatty acids and vitamins produced by commensal and probiotic bacteria. Microb. Cell Fact. 2017, 16, 79. [CrossRef] [PubMed]

Publisher's Note: MDPI stays neutral with regard to jurisdictional claims in published maps and institutional affiliations.

(C) 2020 by the author. Licensee MDPI, Basel, Switzerland. This article is an open access article distributed under the terms and conditions of the Creative Commons Attribution (CC BY) license (http://creativecommons.org/licenses/by/4.0/). 